\title{
Microplastic Polymers in Surface Waters and Sediments in the Creeks Along the Kenya Coast, Western Indian Ocean (WIO)
}

\author{
Joyce O Kerubo ${ }^{1 *}$, John M Onyari ${ }^{2}$, Agnes W N Muthumbi ${ }^{1}$, Deborah Robertson Andersson ${ }^{3,4}$, \\ Edward Ndirui Kimani ${ }^{5}$
}

\author{
${ }^{1}$ School of Biological Sciences University of Nairobi, Nairobi, KENYA \\ ${ }^{2}$ Department of Chemistry, School of Physical Sciences, University of Nairobi, Nairobi, KENYA \\ ${ }^{3}$ School of Life Sciences, University of KwaZulu-Natal, Durban, SOUTH AFRICA \\ ${ }^{4}$ Chrysalis Nature Training, Kei Mouth, SOUTH AFRICA \\ ${ }^{5}$ Kenya Marine and Fisheries Research Institute (KMFRI), Mombasa, KENYA \\ *Corresponding Author: joycekerubo510@yahoo.com
}

Citation: Kerubo, J. O., Onyari, J. M., Muthumbi, A. W. N., Andersson, D. R. and Kimani, E. N. (2022). Microplastic Polymers in Surface Waters and Sediments in the Creeks Along the Kenya Coast, Western Indian Ocean (WIO). European Journal of Sustainable Development Research, 6(1), em0177. https://doi.org/10.21601/ejosdr/11433

ARTICLE INFO

Received: 20 Jun. 2021

Accepted: 18 Oct. 2021

\begin{abstract}
Whereas the Western Indian Ocean (WIO) has been reported to be polluted with microplastics (MPs). Documented information on the specific polymeric composition of these particles in seawater and sediments along the Kenya coast is insufficient. This study assessed the abundance and types of microplastic polymers in the region. Microplastics were sampled from surface water using $500 \mu \mathrm{m}$ neuston nets and from the sediments using a $3.6 \mathrm{~cm}$-diameter corer. Fourier Transform Infrared (FTIR) spectroscopy, Differential Scanning Calorimetry (DSC) and Nuclear Magnetic Resonance (NMR) were used to identify the MPs polymer types. Four polymer types were identified of which, high-density polyethene was the most abundant at $38.3 \%$, followed by polypropylene (34.6\%), low-density polyethene (27.1\%), and medium density polyethene (17.1\%). The results demonstrate the extent of exposure to microplastics of the region's ecosystems and provide the impetus for proper policy briefs regarding the management and disposal of plastic waste, protect and save oceans rich in biodiversity for sustainable development.
\end{abstract}

Keywords: microplastics, polypropylene, polyethylene, differential scanning calorimetry, Fourier transform infrared, Western Indian Ocean Kenya Coast

\section{INTRODUCTION}

Production of plastic products over the past seventy years has increased rapidly, exceeding 380 million tons in 2016 (Plastics Europe, 2017). This figure is expected to increase threefold by 2060 (Lebreton and Andrady, 2019) because of the exponentially increasing demand for plastic products. In 2010 about 275 million tons of synthetic polymers were produced globally, of which about 4.8 to 12.7 million tons entered the oceans from populations living within $50 \mathrm{~km}$ from the coastline (Jambeck et al., 2015). Owing to covid-19 pandemic, plastic products are being generated rapidly, including surgical gloves and face masks (Khoo et al., 2021). Plastics are suited in many applications because they are lightweight, versatile, solid and durable, potentially transparent, bio-inert, excellent moisture barrier, and low cost. These attributes make plastics excellent packaging material replacing glass, metal, and paper as packaging materials. Pollution of oceans by microplastics is a threat that has attracted global attention, and more research is focused on the problem leading to many publications on ocean plastic pollution (Ryan, 2015). Plastic degradation occurs through physical and biological processes to form microplastics (Andrady, 2011), defined as particles measuring $<5 \mathrm{~mm}$ (Arthur et al., 2009). Microplastics in the oceans are either primarily entering directly as fibres, pellets, granules, or second from the breakdown of microplastics (Andrady, 2015). Macroplastics disintegration occurs by turbulence, wave impact and other physical factors (Wong et al., 2020). Secondary microplastics are usually more than primary microplastics such as microbeads in toothpaste and fibres from fishing nets (Rodriguez et al., 2020).

Marine sediments are habitat to bacteria, and many benthic organisms including mollusks, crustaceans and polychaetes as well as small vertebrates (Brown et al., 2008; Hong et al., 2018; Moore, 2008; Naji et al., 2018), and support plants. They are a net sink for organic carbon (Smith et al., 2016) and a source of other economically important products. Wang et al. (2019) reported that microplastics are in sediments and their abundance would still exist in the future (Auta et al., 
2017). Microplastics could affect the water holding capacity, soil fertility and stable water aggregates (Mai et al., 2018).

Microplastics can harbour a wide range of microbial communities, and rafting organisms absorb and concentrate persistent organic pollutants (POPs) (Rochman et al., 2015). Owing to their bright colour and tiny size, microplastics are ingested by invertebrates and vertebrates (Wang et al., 2020), introducing POPs into the food web (Li et al., 2020; Moore, 2008). Biomagnification occurs at higher up trophic levels (Setala et al., 2014), threatening fish and other marine organisms, even human beings (Sanganyado et al., 2020). Microplastics have been reported to decrease survival and lower fecundity in Tigriopus japonicas Mori 1938 (Lee et al., 2013), cause analogous embryonic development in Lytechinus variegatus Lamark 1938 (Nobre et al., 2015). The accumulation of harmful POPs is likely to cause damage to organisms and ultimately a decrease in biodiversity. So far, studies on MPs in the marine environment in Kenya are limited to the study by Kosore et al. (2018), who studied MPs in surface water and in zooplanktons at Gazi Bay and oceanic waters in the EEZ, Awour et al. (2020), who investigated the presence of MPs in benthic invertebrates, Okuku et al. (2020), who studied marine macro-litter composition and distribution, Okuku et al. (2021), who studied temporal trends in marine litter on Mukomani beach, Okuku et al. (2021), who studied the impact of Covid19 pandemic on marine litter pollution along the Kenya coast, Kerubo et al. (2020), who studied the presence and abundance of microplastics in surface waters in the creeks along the Kenya coast and Kerubo et al. (2021), who studied microplastics in the marine sediments along the Kenya coast.

Although microplastics are omnipresent (Setala et al., 2014), information availed on chemical identification and thermal analysis of plastic polymers in the creeks along the Kenya coast is scarce. This study sought to investigate the abundance and type of microplastic polymers in marine sediments and surface water within Tudor, Port-Reitz, and Mida creeks along the Kenya coast. Knowledge of polymer type is essential for assessing plastic pollution in the marine ecosystem. The data and information generated will provide baseline data following the Kenya government gazette notice no. NEMA (2017) reports that 2334 of $14^{\text {th }}$ March 2017 on ban on plastic carrier bags packages effected on $28^{\text {th }}$ August 2017. It will also provide data and information to formulate plastic waste disposal and management policies to protect the ecosystem rich in terrestrial and marine biodiversity (Rochman, 2016).

The objectives of this study were as follows; i) assess the presence and abundance of microplastics in surface water and sediments ii) identify the microplastic polymer types in surface water and sediments in the creeks along the Kenya coast.

\section{MATERIALS AND METHODS}

\section{Study Site}

The study was carried out in three sites, two (Tudor and Port-Reitz Creek) in Mombasa County and one (Mida Creek) in Kilifi County along the Kenya Coast (Figure 1). The Kenya Coastal has a climate that is influenced by two seasonal monsoons; the Southeast monsoon lasting from April to October is associated with high rainfall $(55-272 \mathrm{~mm})$ and temperature range of $20-31^{\circ} \mathrm{C}$ and the shorter Northeast monsoon (November-March) that is drier with an average annual rainfall of 8-84 mm and hotter $\left(23-32^{\circ} \mathrm{C}\right)$. Salinity (32$35 \mathrm{PSU})$ and water conductivity $(53 \mathrm{Ms} / \mathrm{cm})$ are higher during the dry spell and low during the rainy season (Kitheka, 1998; Obiero and Onyando, 2013).

Tudor creek lies between $04^{\circ} 40^{\prime} \mathrm{S}$ and $39^{\circ} 00^{\prime} \mathrm{E}$ (Bosire et al., 2016; Nguli et al., 2006) and covers a surface area of approximately $20 \mathrm{~km}^{2}$. The creek has a long and deep inlet measuring up to 20 meters long that connects a shallower inner basin to the open ocean (Nguli et al., 2006). Tudor creek comprises three parts; the marine mouth (30 m deep), the middle section (less than $5 \mathrm{~m}$ deep), and the upstream $(<1 \mathrm{~m}$ deep), which splits into different channels. The creek experiences semi-diurnal tides with an average mean height of $3.2 \mathrm{~m}$ and $1.1 \mathrm{~m}$ at spring and neap tides. Tudor creek is fed by two main seasonal rivers, Kombeni and Tsalu, which arise from around Mariakani town, $32 \mathrm{~km}$ Northwest of Mombasa (Kitheka et al., 1999). River Kombeni drains about 45,000ha while Tsalu drains 10,000ha (Bosire et al., 2014; Nyamao and Ogendi, 2018). An estimated $0.9 \mathrm{~m}^{3} \mathrm{~s}^{-1}$ of water is discharged into the creek, with the highest discharge occurring between April and June at $1.8 \mathrm{~m}^{3} \mathrm{~s}^{-1}$ (Wakwabi and Mees, 1999). The creek is surrounded by populated informal settlements and villages such as Mushomoroni, Mikindani, Coast General Hospital, and Kenya Meat Commission as a result of rapid urbanisation that has driven the need for labour force in the manufacturing industries, service industries, and the Port of Mombasa (Maritim et al., 2016; Okuku et al., 2011). The inner basin is fringed by mangrove forests, mainly Rhizophora mucronata and Avicennia marina and mudflats (Mirriam, 2010; Nguli et al., 2006; Owuor et al., 2019). Tudor creek passes under Nyali Bridge and is bordered by the Makupa causeway, which separates Tudor to the East from Port-Reitz to the West (Kitheka et al., 1999).

Port-Reitz Creek lies to the south of Mombasa Island $\left(04^{0}\right.$ $04^{\prime} \mathrm{S}$ and $39^{\circ} 39^{\prime} \mathrm{E}$ ) and occupies an area of $1480 \mathrm{~km}^{2}$ (Kamau, 2002). It experiences a semi-diurnal tidal pattern with an average mean height of 1 and $2.5 \mathrm{~m}$ at the neap and spring tides, respectively (Kamau, 2002). Port-Reitz creek receives freshwater from Mwache, Cha Shimba, and Mwambone (Kitheka et al., 1999). Mwache river discharges 215 million $\mathrm{m}^{3}$ of water annually, equivalent to $6.2 \mathrm{~m}^{3} \mathrm{~s}^{-1}$ (UNEP, 1998). The creek is surrounded by highly populated villages such as Dongo Kaya, Dunga Nusa, and Ngala (Maritim et al., 2016; Okuku et al., 2011), Shimanzi, Makunde, and Kibarani (Kamau, 2002). The creek has heavy human activities ranging from the settlement, industrial (kipevu power generation station, Kenya ports authority, and heavy commercial transport deports) to municipal waste dumping site (Kibarani dumpsite). Port-Reitz creek is fringed by mangrove forests, mainly Rhizophora mucronate, Ceriops tagal, and Avicennia marina on the inner basin (Mirriam, 2010; Nguli et al., 2006; Owuor et al., 2019).

Mida creek is a tidal inlet located on the North Coast of Kenya in Kilifi District at longitude $39^{\circ} 58^{\prime} \mathrm{E}$ and latitude $03^{\circ}$ 22'S (Gang and Agatsiva, 1992; Kitheka et al., 1999). Mida creek lacks river inflow. Instead, the creek receives freshwater through seepage from the ground and stormwater runoff 


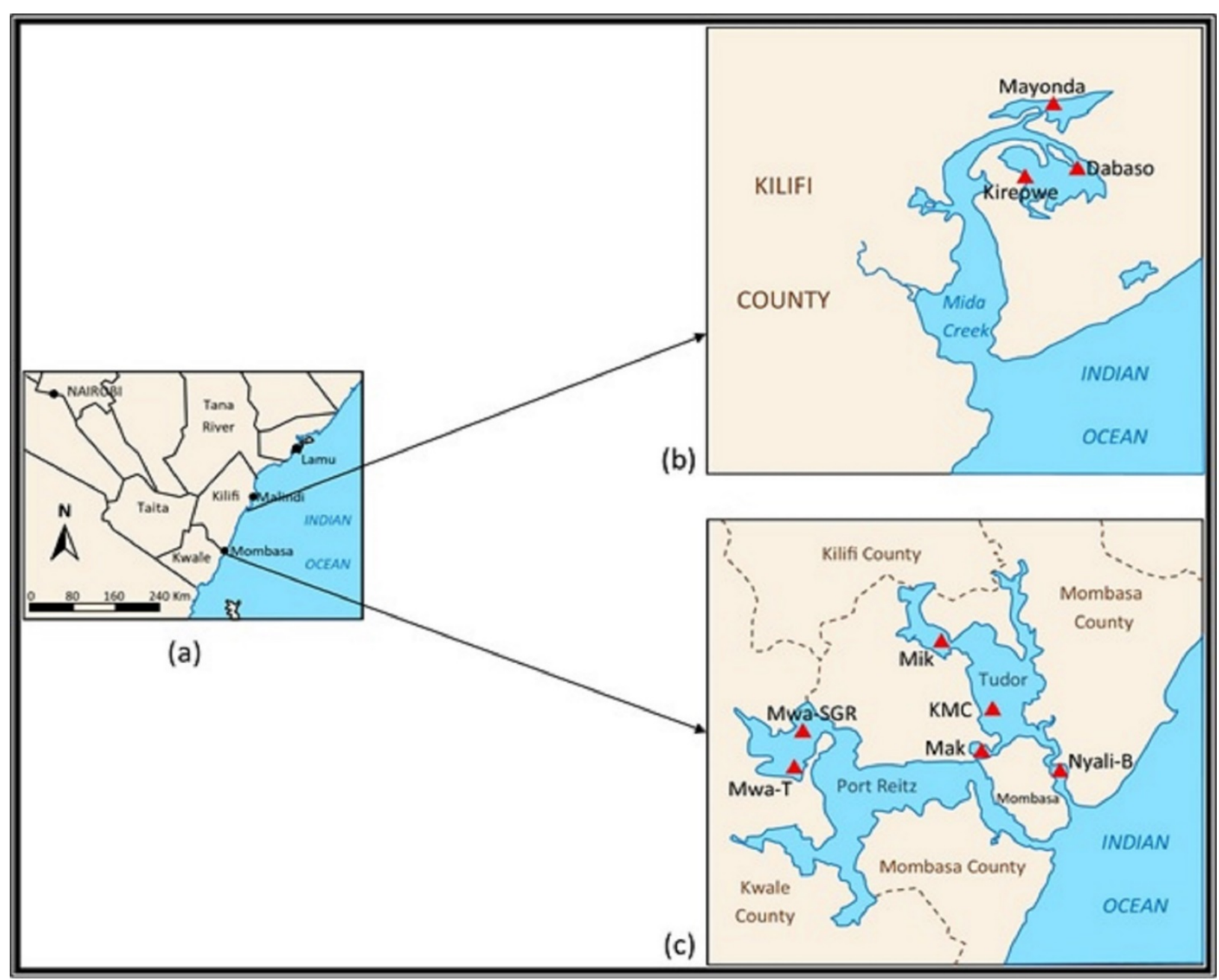

Figure 1. Map of Kenya showing the sampling sites and stations a) Kenya Coastal region; b) Mida Creek; c) Mombasa Island with Tudor and Port-Reitz Creeks. Key: Mak- Makupa, Mik- Mikindani, KMC- Kenya Meat Commission, Mwa-T- Mwache Tsunza, Mwa-SGR- Mwache Standard Gauge Railway, Nyali-B- Nyali -Bridge

(Kitheka et al., 1999; Osore et al., 2004). In addition, the creek is in a marine reserve area, forming part of the Watamu Marine National Park and Reserve (KWS, 1997; Osore et al., 2004). Mida creek receives an average annual rainfall of between 600 $100 \mathrm{~mm}$, with a rainfall season starting in May to September (GOK, 1989). The creek has a constricted narrow entrance and rough bottom that generate modified currents that show significant spatio-temporal variations, although they are generally gentle (Kitheka, 1998). The lower parts of the creek are relatively shallow with a maximum depth of about $7.0 \mathrm{~m}$, but this increases to $11.0 \mathrm{~m}$ in the central lower region and about $4 \mathrm{~m}$ in the wide shallow basin to the north (Kitheka, 1998). Mida creek experiences a semi-diurnal tidal pattern with an average mean height of $2.0 \mathrm{~m}$ and $3.2 \mathrm{~m}$ at the neap and spring tides. The speed of currents at the entrance (mouth) is high, reaching $3.2 \mathrm{~m} / \mathrm{s}$ that reduce to $2.0 \mathrm{~m} / \mathrm{s}$ in the middle and $1.0 \mathrm{~m} / \mathrm{s}$ further inland (Kitheka, 1998; Mwaluma et al., 2003). Partially sub-merged sills near the entrance and the narrow opening prevent faster turnover of water. Consequently, water in the creek is higher in salinity than in the open sea (Yap and Landoy, 1986). The flow is flood-dominated in the main creek channel compared to the backwater region (Kitheka, 1998). Next to Sudi Island, the tides are asymmetrical, with ebb flow dominant compared to flood flow. Water conductivity is highest $(53 \mathrm{Ms} / \mathrm{cm})$ during the dry spell and low during the rainy season (Kitheka, 1998). The ecosystem consists of mangrove forests, mainly Rhizophora mucronate and Ceriops tagal (Kairo et al., 2002).

\section{Sampling Strategy}

Three stations at each of the three sites, Tudor, Port Reitz, and Mida creeks, were identified for sampling. Mida creek being within a national marine reserve situated in a relatively semi-pristine area was considered a control. Sampling was done twice: January/February 2018 and September 2018 to collect sea surface water and sediments. At each station, GPS coordinates were recorded using a handheld GPS (version; Mitac mio168), and various physicochemical parameters were determined using a multi-parameter meter (YSI ProDSS): water conductivity $\left(\mu \mathrm{S} \mathrm{cm}^{-1}\right)$, salinity (PSU), and temperature $\left({ }^{\circ} \mathrm{C}\right)$.

\section{Sampling}

Water samples: A $500 \mu \mathrm{m}$ size neuston net fitted with a flow meter was towed for 10 minutes to collect water samples. Towing was replicated thrice for each station. Material on the net was rinsed into glass bottles using sieved seawater, and the bottle was corked with aluminium foil-lined lids. The samples collected were stored at $-6^{\circ} \mathrm{C}$, awaiting processing. 
Sediment samples: At each station, three intertidal sediment samples were obtained by coring to a depth of $10 \mathrm{~cm}$ using a $3.6 \mathrm{~cm}$-diameter hand corer and replicated thrice, giving a total of 54 samples from the two sampling seasons. The samples were kept in glass sample bottles and covered with metal lids lined with aluminium foil and taken to the laboratory.

\section{Sample Processing and Microplastic Extraction}

Water samples: Water samples were processed as described by Kerubo et al. (2020). Sediment samples: Samples were transferred onto aluminium foil and dried separately at $60^{\circ} \mathrm{C}$ (Clark et al., 2017) until a constant mass was attained. The dry samples were homogenised, weighed, and screened over sieves of $5 \mathrm{~mm}$ and $500 \mu \mathrm{m}$ mesh sizes on a shaker to obtain $500-4999$ $\mu \mathrm{m}$ size grains. The dry sediments were weighed and placed in $800 \mathrm{ml}$ beakers into which $10 \% \mathrm{KOH}$ was added in the ratio of $1 \mathrm{~g}$ sediment to $5 \mathrm{ml} \mathrm{KOH}$, stirred thoroughly for 5 minutes using a glass rod, and left to digest for 14 hours at $60^{\circ} \mathrm{C}$ (Hidalgo-Ruz et al., 2012). After cooling, density separation was conducted to extract microplastics (Coppock et al., 2017; De Witte et al., 2014; Thompson et al., 2004) by adding a supersaturated $\mathrm{NaCl}$ solution $(358.9 \mathrm{~g} / \mathrm{L}$ of deionised water) in the ratio of $1 \mathrm{~g}$ sediment to $10 \mathrm{ml} \mathrm{NaCl}$ solution. The mixture was stirred for 10 minutes using a glass rod, covered with aluminium foil then left for 12 hours for sedimentation of sand particles. The procedure was repeated thrice for each sediment sample with sedimentation time adjusted to 6 hours (De Witte et al., 2014; Thompson et al., 2004) for the second and third time to ensure all microplastics were recovered through floatation. The supernatant vacuum pump filtration was done over a $20 \mu \mathrm{m}$ pore size membrane filter for each sample separately. Filters were kept in lidded filter dish holders, dried at $40^{\circ} \mathrm{C}$ for 12 hours, and examined under the microscope. Microscopic examination was done as described earlier.

\section{Polymer Identification}

DSC: Polymer characterisation was done using Differential Scanning Calorimetry (DSC) (Courtene-Jones et al., 2017; Onyari et al., 2008). DSC allows the measuring of crystallisation temperature $\left(\mathrm{T}_{\mathrm{c}}\right)$, glass transition $\left(\mathrm{T}_{\mathrm{g}}\right)$, and melting temperature $\left(\mathrm{T}_{\mathrm{m}}\right)$ while a polymeric sample is being heated or cooled (Courtene-Jones et al., 2017). Samples weighing between 0.9-2.7 mg were measured using the DSC Q100 V9.9 model, while the DSC profiles were analysed using aV4.5A TA Universal Analysis Software. Experimental temperatures used ranged between -25 and $250^{\circ} \mathrm{C}$ at a heating rate of $10^{\circ} \mathrm{C} / \mathrm{min}$. The characteristic temperatures $\left(\mathrm{T}_{\mathrm{g}}, \mathrm{T}_{\mathrm{m}}\right.$, and $\mathrm{T}_{\mathrm{c}}$ ) were obtained after removing the thermal history of the samples by running first and second DSC scans.

FTIR: FT-IR is highly reliable in determining the chemical composition of microplastic fragments (Hidalgo-Ruz et al., 2012; Shim et al., 2017). It could present the structural groups and reflect the optical responses of the surface functional groups, being useful in detecting functional groups, characterizing covalent bonding information and data interpretation for polymers (Fan et al., 2021; Ludwig et al., 2018). Subsamples of nine microplastic particles each from surface water and marine sediments were analysed according to Baker et al. (2014) protocol using a Fourier Transform
Infrared (FTIR) spectrometer (Shimadzu IR Affinity-1S, Japan). Cleaning of the ATR diamond crystal was done using absolute ethanol. Before analysing each sample, background scans were performed to eliminate carbon dioxide and humidity for quality spectra. Spectra wavelengths ranged from $4000 \mathrm{~cm}^{-1}$ to $500 \mathrm{~cm}^{-1}$ with data interval of $1 \mathrm{~cm}^{-1}$ and spectra resolution of $4 \mathrm{~cm}^{-1}$. Each sample was placed onto the centre of the crystal plate and the pressure pump lowered by turning the control knob, compressing the sample against the diamond to ensure good contact between the sample and the ATR crystal. Absorption spectra were recorded and identified by comparison with polymers in the research gate spectra library and literature.

NMR: NMR is fast, size independent and has high accuracy. It identifies and quantifies the type of branching present in a polymer and provides molecular structure information (Peez et al., 2019). Sub-samples from all the nine stations were analyzed. Samples were prepared by complete dissolution in the specimen tube using appropriate deuterated solvents and temperature. The samples obtained from fish (F), water (W) and sediments (S) were dissolved overnight in the deuterated benzene and proton NMR done using a $600 \mathrm{MHz}$ Bruker Avance NEO equipped with a nitrogen cooled TCI cryoprobe (gives 24 times better signal-to-noise than regular probes). Spectra obtained were compared with spectra in the literature.

\section{Quality Control}

Peng et al. (2017), and Kanhai et al. (2017) methods were followed to ensure quality control. Filters were placed in lidded filter dish holders and covered with aluminium foil. Processing and analysis of samples were done in a clean room with negative airflow and limited foot traffic. Glassware and metal equipment were rinsed with distilled water, and procedural blanks were set up ( 1 blank per three samples analysed) and analysed for any potential contaminants. The counts per blank were subtracted from the total count in each sample to correct ground contamination. The working surface was cleaned with $70 \%$ ethanol. Hand gloves and a cotton laboratory coat were used throughout the sample processing and analysis period.

\section{Data Analyses}

Data were processed using the Statistics and Data (STATA) version 15 . Data normality was checked by doing the ShapiroWilk W test. Data sets that were not normally distributed were log-transformed, after which the parametric test of ANOVA was used for data with normal distribution, while the KruskalWallis (non-parametric) test was used for data that failed the normality test. The total mean concentration and the concentrations of microplastics were assessed between sites (Tudor, Port Reitz, and Mida Creeks) and between stations in each of the sites. The results were considered significant at $\mathrm{p}<$ 0.05 .

\section{RESULTS}

\section{Ocean Physical Factors}

The physical factors of the ocean surface water within the creeks were not significantly different $(p>0.05)$ between seasons and sites. Ocean surface water temperature was 

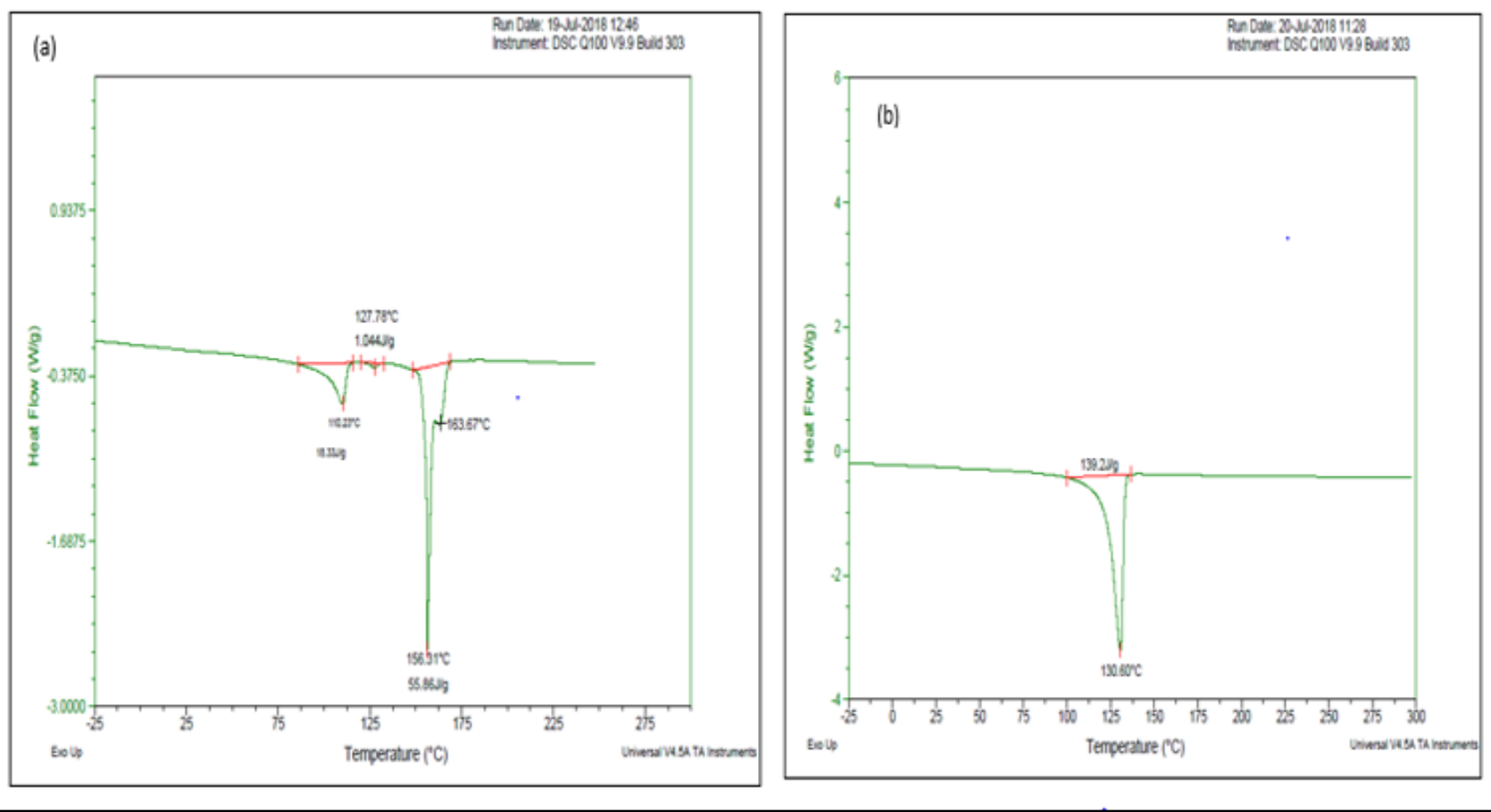

Figure 2. DSC curves (a) MDPE and PP sample SK 7 (b) HDPE sample SK 3 from Tudor creek

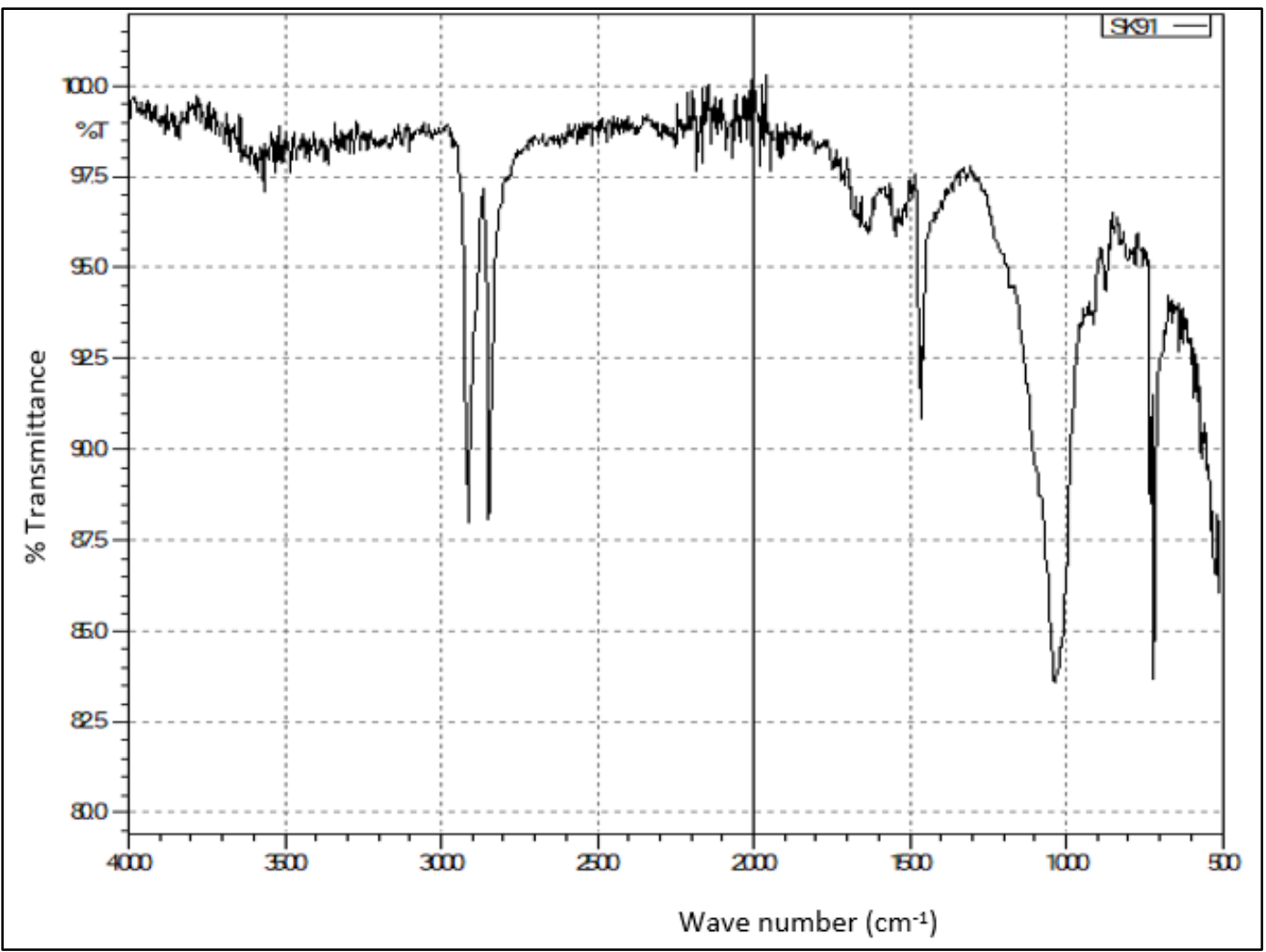

Figure 3. ART- FTIR spectrum of LDPE from Port-Reitz Mwache-SGR

relatively low with Tudor having a mean of $23.6 \pm 0.7^{\circ} \mathrm{C}$, PortReitz $21.9 \pm 0.8^{\circ} \mathrm{C}$, and Mida $22.2 \pm 0.9^{\circ} \mathrm{C}$. Salinity was almost similar in all the sites with Tudor recording a mean of $34.7 \pm$ 0.1 PSU, Port-Reitz $34.5 \pm 0.1$ PSU and Mida $34.4 \pm 0.1$ PSU. Similarly, conductivity was almost the same across the sites, with Tudor having $55810.1 \mu \mathrm{S} \mathrm{cm}^{-1}$, Port-Reitz $55985.1 \mu \mathrm{S} \mathrm{cm}$

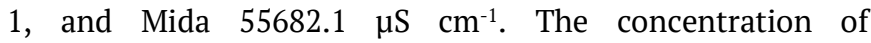

microplastics in the surface water is reported elsewhere in a documentary by Kerubo et al. (2020).

\section{Microplastic Polymer Types and Abundance in Surface Water}

Four different synthetic polymers (LDPE, HDPE, MDPE, and PP) were present in the microplastic samples studied, as 


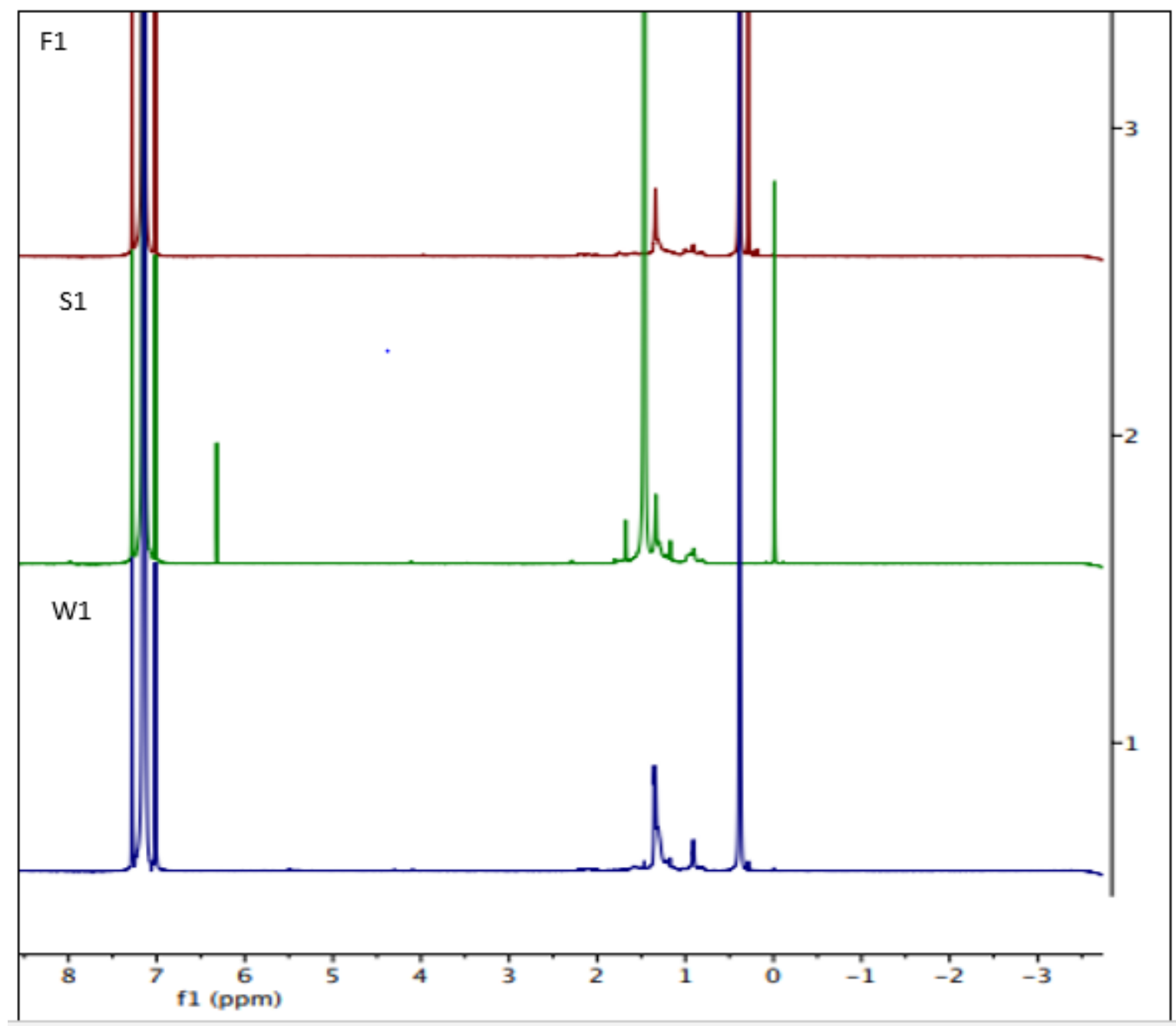

Figure 4. NMR spectrum of microplastics from fish (F1 - Port-Reitz), sediments (S1 - Tudor) and water (W1 - Tudor)

shown in Figures 2 and 3. DSC profile exhibited one melting peak for LDPE that occurred at between $110-115^{\circ} \mathrm{C}$, while DSC for MDPE showed both primary and second temperature peaks falling at $123^{\circ} \mathrm{C}$ and $126^{\circ} \mathrm{C}$, respectively (Figure 2a). The second melting peak could be due to short-chain (lower molecular weight) polymer segments. The melting peak for HDPE is about fifteen degrees higher than that of LDPE (Figure 2b), an indication that HDPE is highly ordered with less branching. The DSC spectra are similar to spectra from the literature (Brandon et al., 2016).

FTIR characterisation of polyethene showed two bands at $2914 \mathrm{~cm}^{-1}$ and $2849 \mathrm{~cm}^{-1}$ due to the $\mathrm{C}-\mathrm{H}$ stretch of the methylene group $\left(\mathrm{CH}_{2}\right)$ (Figure 3). This agrees with values of 2915 and $2845 \mathrm{~cm}^{-1} \mathrm{C}-\mathrm{H}$ stretching vibrations reported by Jung et al. (2018). The peak observed around $1472 \mathrm{~cm}^{-1}$ is attributed to the $\mathrm{CH}_{2}$ bending vibration. A medium $\left(1033 \mathrm{~cm}^{-1}\right)$ and weak $\left(720 \mathrm{~cm}^{-1}\right)$ peaks were observed. The peak at $720 \mathrm{~cm}^{-1}$ could be assigned to $\mathrm{CH}_{2}$ rocking vibration of High-density polyethene (HDPE) as observed by Jung et al. (2018). These results agree with earlier research on polyethene characterisation by FTIR (Gulmine et al., 2002, Jung et al., 2018; Majewski et al., 2016). Majewski et al. (2016) observed that polyethene and polypropylene could be qualitatively identified with DSC by their specific endothermic peak temperatures. Jung et al.
(2018) demonstrated that attenuated total reflectance (ATR FT-IR) analysis could be used to differentiate HDPE and LDPE.

NMR analysis: The microplastics samples showed slight solubility in benzene-d6 and showed no dissolution in other common NMR solvents. Microplastics samples obtained from fish, sediments and water are presented in Figures 4 and 5. All the samples analyzed from the two creeks showed the characteristic methylene protons $\left(\mathrm{CH}_{2}\right)$ chemical shift in the region 1.2 to $1.41 \mathrm{ppm}$ and methyl $\left(\mathrm{CH}_{3}\right)$ protons signals below $1 \mathrm{ppm}$. These results are consistent with observations by Peez et al. (2019) and Long et al. (2021). Further, the proton spectrum for S2 had enough signal to carry out an edited HSQC. The microplastic obtained from sediments (S2) (see Figure 5) showed chemical shifts $\left({ }^{1} \mathrm{H},{ }^{13} \mathrm{C}\right)$ at $6.92,130.43 \mathrm{ppm}$ and 8.13, $129.46 \mathrm{ppm}, 4.28,67.75 \mathrm{ppm}$ and 4.18, 67.27 ppm, $1.21,23.12 \mathrm{ppm}$ to $1.29,23.92 \mathrm{ppm}, 1.51,38.91 \mathrm{ppm}$ to 1.59 , $38.91 \mathrm{ppm}$, and $0.82,10.87 \mathrm{ppm}$ suggesting presence of phthalates. Duchowny and Adams (2021) reported the ${ }^{1} \mathrm{H}$ NMR spectra of various plasticizers. The aromatic peaks were observed in the region approx., $7 \mathrm{ppm}$, the $\alpha-\mathrm{CH}_{2}$ groups next to the ester bond ( 3 to $4 \mathrm{ppm}$ ), aliphatic $\mathrm{CH}_{2}$ (around $1 \mathrm{ppm}$ ) and the $\mathrm{CH}_{3}$ chain ends around $0.8 \mathrm{ppm}$ consistent with the general structure of phthalates derived from phthalic anhydrides. 


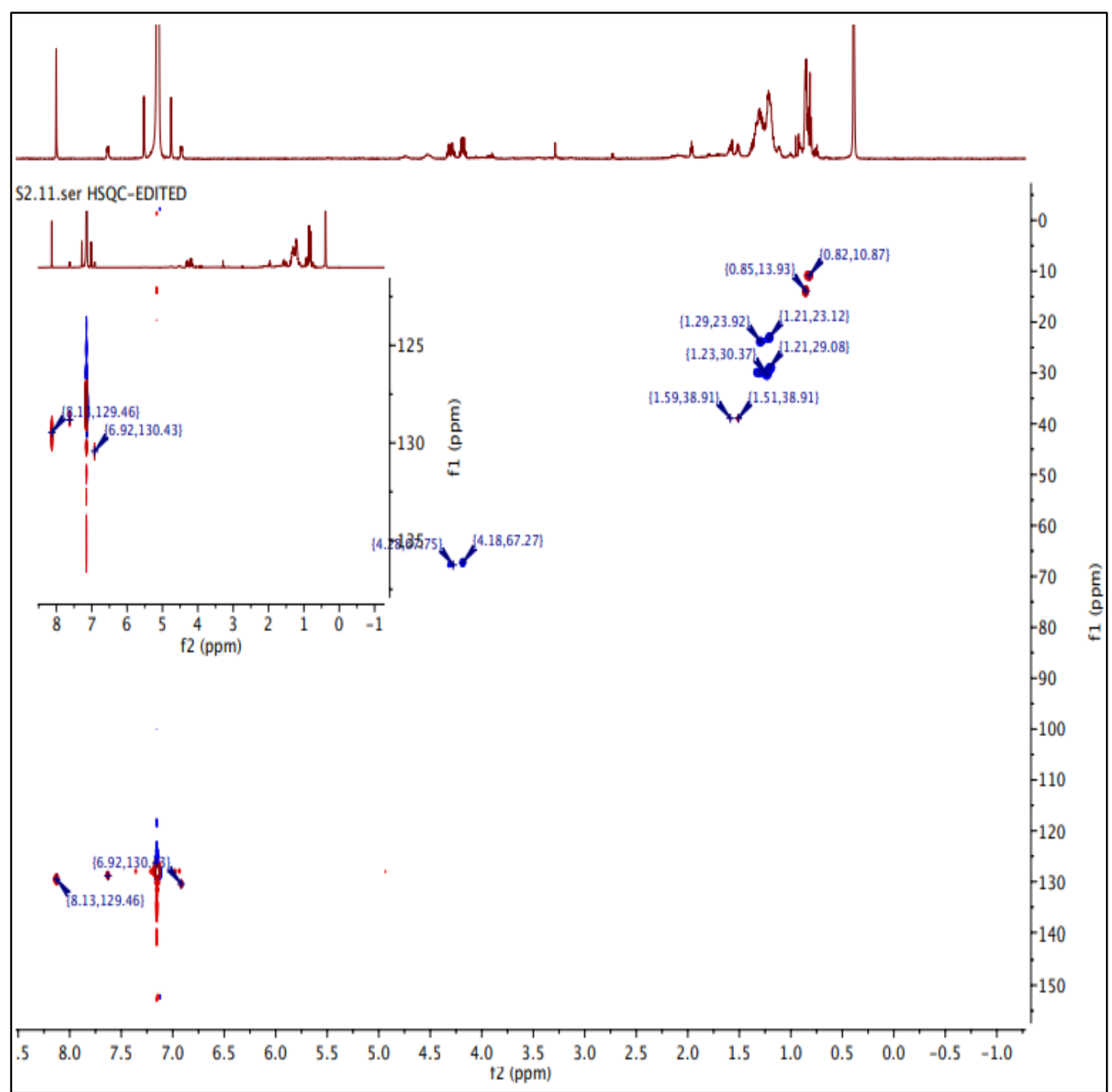

Figure 5. 2D ${ }^{1} \mathrm{H}-{ }^{13} \mathrm{C}$ HSQC of microplastic obtained from sediments (S2 - Mida)

Generally, the concentration of polymer types showed no significant variation $(\mathrm{P}>0.05 \mathrm{df} 2,24)$. However, HDPE was more abundant, accounting for $38.3 \%(8.29 \pm 3.27)$ compared to LDPE $27.1 \%(5.87 \pm 2.6)$ and PP $34.6 \%(7.48 \pm 4.84) \mathrm{mp} . \mathrm{m}^{-}$ ${ }^{3}$ of the total microplastics extracted. These results are similar to research findings from the Minor Italian Islands and the South Ocean (De Lucia et al., 2018). Among sites, HDPE was found to account for $33 \%$; $26 \%$; $19 \%$ of the total polymer particle extracted in Tudor, Mida, and Port-Reitz, respectively, while PP accounted for $33 \%$ of the total microplastic particles extracted in Port- Reitz, compared to 17 and $14 \%$ microplastic particles in Mida, and Tudor respectively (Figure 6). Medium density polyethene (MDPE) was rare, only occurring in Tudor creek surface water with $17 \%$ of the total polymer particles extracted.

\section{The Overall Mean Concentration of Microplastics in Sediments}

Generally, the mean polymer concentration was $1.61 \pm 0.14$ particles $\mathrm{g}^{-1} \mathrm{~d}$.w. of total sediment. These results are similar to those obtained in Southern New England (Mathalon and Hill, 2014), the North Sea (Claessens et al., 2011), and the NorthEast Atlantic (Maes et al., 2017). Microplastic concentrations varied significantly $(p<0.05)$ between sites, and Tudor had a higher concentration compared to Mida and Port-Reitz. Fibres were predominant (Jahan et al., 2019; Martinelli et al., 2020), followed by fragments, while films recorded the lowest mean concentrations across the sites. Mikindani in Tudor, Dabaso, and Mayonda in Mida had a higher microplastic concentration compared to others (Table 1).

Microplastic Polymer Types and Abundance in Sediments

Unlike in surface water samples, three microplastic polymer types were identified. None of the sediment samples tested contained MDPE plastic polymer. The polymer distribution varied between types and HDPE $(0.42 \pm 0.01$ particles g- 1 d.w.) was more compared to LDPE $(0.22 \pm 0.002)$ and PP $(0.18 \pm 0.01)$ particles $\mathrm{g}^{-1}$ d.w. Among sites, the HDPE mean concentration differed significantly $(p<0.05)$ and was higher in Tudor $\left(0.53 \pm 0.015\right.$ particles $\mathrm{g}^{-1} \mathrm{~d}$.w.) (33 \%) followed by Mida and Port-Reitz $(0.45 \pm 0.041$ and $0.27 \pm 0.023)$ particles $\mathrm{g}^{-1}$ d.w (28\%, $\left.17 \%\right)$ of the total polymer particles extracted respectively (Figure 6). Similarly, LDPE mean concentrations were higher in Mida $\left(0.27 \pm 0.017\right.$ particles $\left.\mathrm{g}^{-1} \mathrm{~d} . \mathrm{w}\right)$. The mean concentration for PP showed no significant difference $(\mathrm{p}>$ $0.05)$ but was more abundant in Tudor $(0.27 \pm 0.127$ particles $\mathrm{g}^{-1}$ d.w. $\left.17 \%\right)$. 


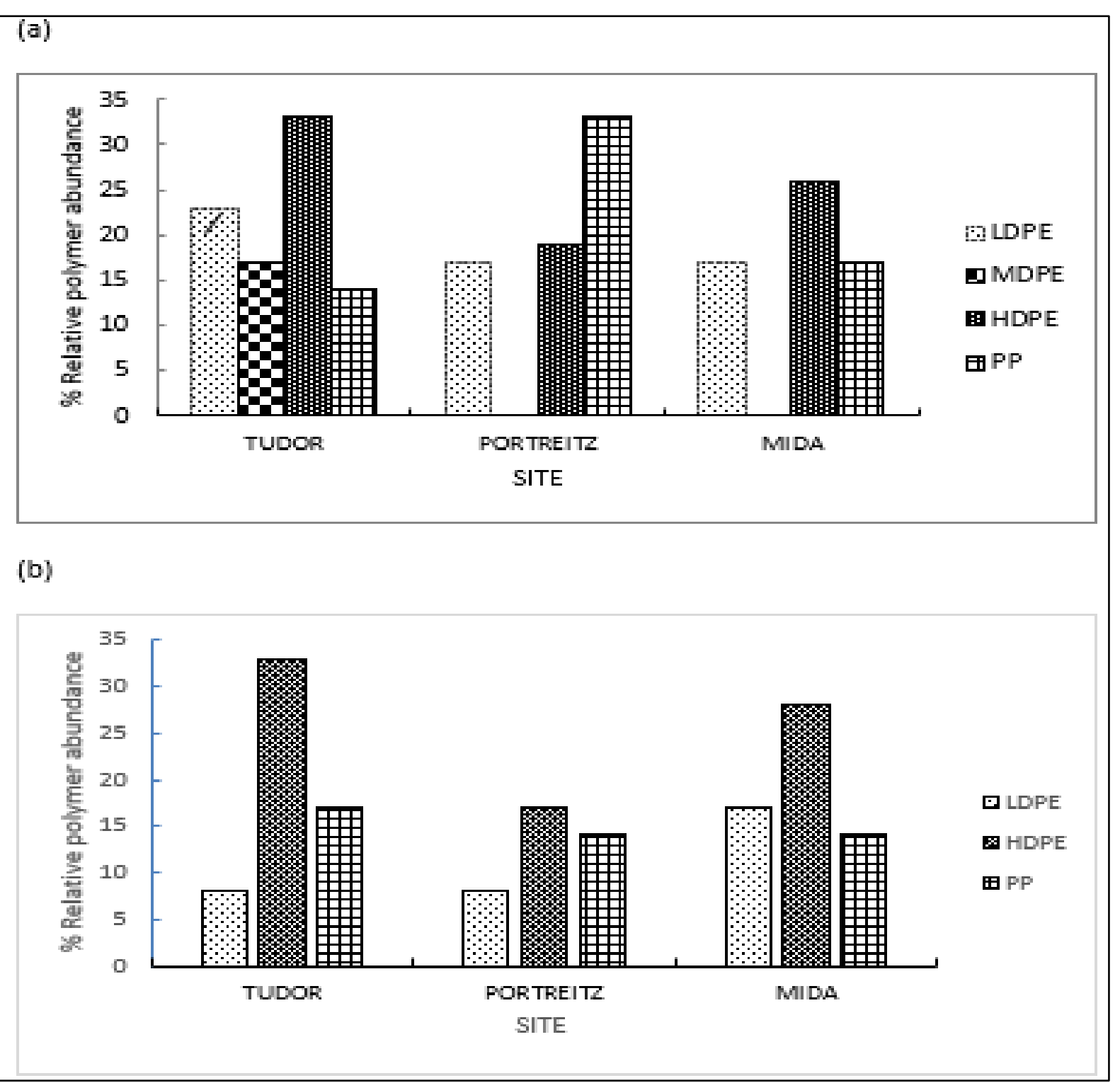

Figure 6. Differences in relative abundance (\%) of the polymer types between sites as identified by DCS and FTIR: a) surface water microplastic polymers $(n=685) b)$ sediments microplastic polymers $(n=1140)$

Table 1. Total mean ( $\left.\mathrm{Z}^{\exists} \mathrm{SE}\right)$ concentration $\left(\mathrm{g}^{-1} \mathrm{~d} . \mathrm{w}.\right)$ and types of microplastics in sediments from the different sites and stations

\begin{tabular}{|c|c|c|c|c|c|c|}
\hline \multirow[b]{2}{*}{ Site } & \multicolumn{6}{|c|}{$\left(\mathrm{x}^{-} \pm \mathrm{SE}\left(\mathrm{g}^{-1}\right.\right.$ d.w. $)$} \\
\hline & Total mean mps & Fibre & Fragment & Film & Station & Total mean mps \\
\hline \multirow{3}{*}{ Mida } & \multirow{3}{*}{$1.24 \pm 0.09$} & \multirow{3}{*}{$1.13 \pm 0.2$} & \multirow{3}{*}{$0.08 \pm 0.01$} & \multirow{3}{*}{$0.02 \pm 0.0$} & Dabaso & $1.5 \pm 0.087$ \\
\hline & & & & & Kirepwe & $0.981 \pm 0.150$ \\
\hline & & & & & Mayonda & $1.53 \pm 0.066$ \\
\hline \multirow{3}{*}{ Port-Reitz } & \multirow{3}{*}{$1.03 \pm 0.01$} & \multirow{3}{*}{$0.95 \pm 0.01$} & \multirow{3}{*}{$0.05 \pm 0.01$} & \multirow{3}{*}{$0.03 \pm 0.01$} & Makupa & $1.43 \pm 0.220$ \\
\hline & & & & & Mwa-T & $1.052 \pm 0.149$ \\
\hline & & & & & Mwa-SGR & $0.623 \pm 0.137$ \\
\hline \multirow{3}{*}{ Tudor } & \multirow{3}{*}{$1.58 \pm 0.13$} & \multirow{3}{*}{$1.45 \pm 0.3$} & \multirow{3}{*}{$0.09 \pm 0.01$} & \multirow{3}{*}{$0.04 \pm 0.01$} & Mikindani & $2.18 \pm 0.225$ \\
\hline & & & & & KMC & $1.33 \pm 0.187$ \\
\hline & & & & & Nyali-B & $1.26 \pm 0.210$ \\
\hline $\mathrm{Df}$ & 2,141 & 2,141 & 2,141 & 2,141 & & 8 \\
\hline F-value & 6.408 & 5.995 & 6.494 & 1.956 & & 4.76 \\
\hline p-value & 0.00217 & 0.00317 & 0.002 & 0.145 & & $<0.01$ \\
\hline
\end{tabular}

Key: KMC - Kenya Meat Commission, Mwa-T - Mwache Tsunza, Mwa-SGR - Mwache Standard Gauge Railway, Nyali-B - Nyali Bridge. 


\section{DISCUSSION}

Kenya, like other countries in the world consumes plastic products. Kenya's daily plastic consumption is estimated at $0.03 \mathrm{~kg}$ per person. In 2017, Kenya imported about 4500057000 metric tonnes of plastic (Elliott et al., 2018). However, the country's legislative framework to plastic waste management is unpredictable and the country lacks waste management infrastructure. However, Kenya adapted the circular economy and also effected a ban on production, import and use polythene plastic bags in August 2017. The ban has had a success rate of $80 \%$ and reduced polythene plastic bags along the coastline, National Parks and drainages (GOK Ministry of Environment and Forestry, 2020).

Our results on microplastic concentrations in surface water were higher compared to observations from other parts of the world. For example, by De Lucia et al. (2014), using a 333 $\mu \mathrm{m}$ manta net, Lusher et al. (2015), by pumping and sieving water, and Kosore et al. (2018), by sieving surface water from from the open sea along the Kenya coast using a $250 \mu \mathrm{m}$ sieve. The results on microplastic concentrations in sediments were consistent with observations by Mathalon and Hill (2014), Claessens et al. (2011), and Maes et al. (2017). Majority of the Microplastics in our study were fibers which was consistent with observations by Partterson et al. (2019), Jahan et al. (2019), Martinelli et al. (2020). This suggested that the source of microplastics in the ecosystem was fibrous materials such as clothes and ropes (Wright et al., 2013) which are a common component of marine debris from wastewater due to washing clothes (Browne et al., 2011) and fishing activity (Wright et al., 2013).

It is shown in this study that FTIR, DSC and NMR can be used to identify the presence of microplastics in Kenya's marine environment. The use of two or more methods for polymer identification reduces multiple interpretations and increases the chances of correct identification. However, FTIR cannot identify black particles (Kappler et al., 2016) and gives limited information about the functional groups present in a polymer structure. The force applied to samples to ensure good contact can indent vulnerable samples (Mitchell et al., 2013). The NMR analysis results suggest that the microplastic samples studied contain polyethylene and the chemical shifts observed are consistent with other studies done (Moradi et al., 2019; Peez et al., 2019). The 2D ${ }^{1} \mathrm{H}^{13} \mathrm{C}$ Heteronuclear Single Quantum Coherence (HSQC) of microplastics suggest the presence of phthalates as indicated in the HSQC data above. The presence of phthalates may be due to additives added to plastics as plasticizers or small molecules. Furthermore, the aromatic signal around $7 \mathrm{ppm}$ for microplastics (S2) can be used to differentiate types of plasticizers such as diisononyl cyclohexane-1,2-dicarboxylate (DINCH) from others such as diethylhexyl phthalate and diisobutyl phthalates as described by Duchowny and Adams (2021). Of particular interest, plasticizers constitute about one third of polymer additives (Rahman, 2004) and global demand for plasticizers is expected to increase from $\$ 78.91$ billion in 2020 to $\$ 87.81$ billion in 2021 according to a recent report (Researchandmarkets.com). Zhang et al. (2021) recently reviewed the hazards of phthalates (PAEs) exposure. Therefore, surveillance and monitoring of presence of Phthalate Esters, plasticizers phthalates in microplastics in marine environment is of global interest.

Polyethene is used in; i) packaging applications such as pharmaceutical and squeeze bottles, caps and closures, tamper-evident liners, trash bags, films for food packaging, bubble wraps, thick shopping bags, laminations, crates, trays, bottles for milk, juice fruits, caps for food packaging, jerrycans, drums, industrial bulk containers among others; ii) consumer goods such as garbage containers and refuse sacks, housewares, ice boxes, toys among others iii) fibres and textiles such as in ropes, fishing, and sports nets, nets for agricultural use, industrial and decorative fabrics among others, iv) pipes and fittings such as pipes for gas, water, sewage, drainage, sea outfalls, industrial application cable protection, steel pipe coating among others, v) automotive products such as fuel tanks, wiring, and cables for sheeting of energy, telecommunication cables among others (Chen and Chen, 2020; Patel, 2016;Error! Hyperlink reference not valid.). Like PE, in addition to packaging applications, PP is used in the production of electronic products, films, graphics art applications, disposable diaper tabs and closures, furniture applications, crates, bottles and pots, translucent parts, houseware, luggage, toys, automotive appliances such as battery cases and trays, bumpers and fender liners, slit films, tape, strapping, staple fibres, ropes and twines, medical application products such as disposable syringes, medical vials, diagnostic devices, intravenous bottles, petri dishes, food trays, pans, pill containers among others, and industrial application products such as acid and chemical tanks, sheets, pipes, returnable transport packaging among others (Patel, 2016). All these plastic products are likely to leak into the environment leading to contamination.

Low-density polymers, mainly PE and PP, were observed in both water and sediment environments, which was no surprise because they are among the polymer types that accounted for $74 \%$ of global plastic production in 2015 and are the leading polymers in plastic production commonly used in short-cycle products (Geyer et al., 2017: Plastics Europe, 2017). PE is important in synthetic polymer commonly used in packaging and textile (Wang et al., 2021). High-density polyethene polymers predominated in surface water (38.8\%) and sediments $(51.2 \%)$. Our results were consistent with observations by Yuan et al. (2019), and Zhang et al. (2020), but contradicted observations by Liao et al. (2021). High-density particles can enter the water column by resuspension of the bottom sediment. Nearshore circulation and offshore tides influence sediment resuspension in water estuaries contributing to redistribution and discharge of substances between water and sediments. The presence of low-density polymers in sediments can be attributed to change in densities with weathering and biofouling in the water and strong turbulence caused by wind, waves, or currents that cause sedimentation of the polymers (Kukulka et al., 2012). Our results show that low-density polymers are widely distributed in both water and sediment environments. In contrast, highdensity polymers were not observed, which could imply different transport and deposition mechanisms while suggesting sewage, synthetic textiles, packaging material, and fishing gear as essential sources of the MPs (Browne et al., 2010; Cole et al., 2014) in the creeks along the Kenya coast. 
Microplastics of different polymers occurred in sediments and surface water samples from all sites, including Mida creek, within Watamu National Marine Reserve thought to be safe from pollution by industrial effluents, sewage disposal, and fishing activities. This can be due to the high tourism activity, boat and dhow fishing activities (own observation), densely populated villages such as Dabaso, Ngala, and Kirepwe (Nyamao and Ogendi, 2018; Okuku et al., 2011), and the mangrove vegetation cover of tall trees that bind soil particles favouring microplastic accumulation.

Tudor creek is fed by two major seasonal rivers, Kombeni and Tsalu (Bosire et al., 2016; Kitheka, 1999; Nyamao and Ogendi, 2018)), which collect runoff with plastic and other waste debris from the mainland and discharge them into the creek. The creek experiences solid waves and currents (Kitheka, 1999), but the shore had a reasonably thick mangrove vegetation cover (own observation) whose roots bind sediments together to hold microplastic particles. Rapid urbanisation has led to the development of heavy industries at Changamwe and densely populated informal settlements like the Mikindani, Coast General Hospital, and KMC settlements (KNBS, 2019; Okuku et al., 2011) around the creek that may be adding onto the microplastics brought in by the seasonal rivers and ocean currents through the release of domestic raw waste. The many industries in Mombasa Island release their effluents into the sea, thereby increasing microplastics in sediments but, this study did not determine the proportions.

Humans are at a risk of microplastic exposure through consumption and inhalation in daily life (Cox et al., 2019). Understanding the contents of microplastics in the environment will contribute to a better understanding of the impact of microplastics on the environment. It is important to reduce excessive production and use of disposable plastic waste. However, consumption of disposable plastics continues to increase due to increasing demand in food packaging ( $\mathrm{Chu}$ et al., 2020), Covid-19 pandemic (Silva et al., 2020), and increased production and global consumption. It is therefore important to promote public environmental awareness and better governance.

\section{CONCLUSIONS AND RECOMMENDATIONS}

The results from the study provide evidence that the marine environment along the Kenya coast is polluted with microplastics. The analysis showed that physiographic factors did not influence the distribution of microplastics. The accumulation of microplastic polymers within the creeks may be of serious concern because of their ability to absorb and concentrate POPs, passing the toxins up trophic levels when ingested by plankton species. Marine planktons form the base of the marine food web, and any threat to them may have severe negative impacts on the oceans. There is a need of quantifying the levels and establishing the sources of synthetic polymers in the creeks along the Kenya coast and assess the future impacts of soaring microplastic levels on oceans globally.

FT-IR, DSC and NMR analyses showed the absence of highdensity polymers such as polyvinylchloride and polyethene Terephthalate, probably due to the medium of extraction used.
The Sodium Chloride solution used has lower density and could have favoured the extraction of low-density microplastic compared to high density polymers such as PVC. Therefore, the concentration of microplastics in the WIO region along the Kenya coast may have been underestimated. This study recommends that further research be done using a different medium of extraction and subject the microplastic samples to TGA and GC-MS analysis to detect other types of polymers present in the marine ecosystems.

This study provides insights into the presence, concentration, and type of microplastic polymers, providing a baseline for monitoring microplastics along the Kenya coast. The information also offers a basis for evaluating the effect of the Kenya government ban effected in August 2017 on low weight plastic bag production and use in Kenya (NEMA, 2017). This study is essential since the knowledge can be used for proper policy formulation regarding plastic production, waste management, and disposal to save oceans rich in biodiversity.

There is a need to critically evaluate Kenya's plastic waste disposal policy to curb the problem. The Kenya Government should protect the ocean through legislation on plastic waste management, compelling producers to meet the cost of plastic waste disposal and management, encourage the development of plastic recycling industries by creating assistance programs for those in need of waste management system expertise. Manufacturers should produce alternative packaging materials to plastics such as sisal bags.

Author contributions: All co-authors were involved in all stages of this study while preparing the final version. They all agree with the results and conclusions.

Funding: We would like to thank the National Research Fund for financial support, Dr. Reuben Bosire and Dr. Daniel Holmes (MSU), the University of Nairobi, the KMFRI technical staff for their generous and technical support.

Declaration of interest: The authors declare that they have no competing interests.

Ethics approval and consent to participate: Not applicable.

Availability of data and materials: All data generated or analyzed during this study are available for sharing when appropriate request is directed to corresponding author.

\section{REFERENCES}

Andrady, A. L. (2011). Microplastics in the marine environment. Marine Pollution Bulletin, 62(8), 1596-1605. https://doi.org/10.1016/j.marpolbul.2011.05.030

Andrady, A. L. (2015). Persistence of plastic litter in the oceans. In Marine Anthropogenic litter (pp. 57-72). Springer. https://doi.org/10.1007/978-3-319-16510-3_3

Arthur, C. D., Baker, J. and Bamford, H. (Eds.) (2009). Proceedings of the International Research Workshop on the Occurrence, Effects, and Fate of Microplastic Marine Debris. September 9-10, 2008; Tacoma, WA. NOAA Technical Memorandum NOS-OR\&R-30.

Auta, H. S., Emenike, C. U. and Fauziah, S. H. (2017). Distribution and importance of microplastics in the marine environment: a review of the sources, fate, effects, and potential solutions. Environment International, 102, 165176. https://doi.org/10.1016/j.envint.2017.02.013 
Awuor, W., Muthumbi, A. W. N. and Robertson-Andersson, D. V. (2020). Presence of microplastics in benthic macroinvertebrates along the Kenyan coast, African Journal of Marine Science, 42(4), 405-411. https://doi.org/10.2989/1814232X.2020.1829045

Baker, M. J., Trevisan, J., Bassan, P., Bhargava, R., Butler, H. J., et al. (2014). Using Fourier transform IR spectroscopy to analyse biological materials. Nature protocols, 9(8), 17711791. https://doi.org/10.1038/nprot.2014.110

Bosire, J., Mangora, M., Bandeira, S., Rajkaran, A., Ratsimbazafy, R., Appadoo, C. and Kairo, J. (2016). Mangroves of the Western Indian Ocean: Status and management. Zanzibar Town: WIOMSA.

Brandon, J., Goldstein, M. and Mark, D. O. (2016). Long-term aging and degradation of microplastic particles: Comparing in situ oceanic and experimental weathering patterns. Marine Pollution Bulletin, 110, 299-308. https://doi.org/10.1016/j.marpolbul.2016.06.048

Browne, M. A., Crump, P., Niven, S. J., Teuten, E., Tonkin, A., Galloway, T. and Thompson, R. (2011). Accumulation of microplastic on shorelines worldwide: sources and sinks. Environmental Science and Technology, 45(21), 9175-9179. https://doi.org/10.1021/es201811s

Browne, M. A., Dissanayake, A., Galloway, T. S., Lowe, D. M. and Thompson, R. C. (2008). Ingested microscopic plastic translocates to the circulatory system of the mussel, Mytilus edulis (L.). Environmental Science Technology, 42(13), 5026-5031.

Browne, M. A., Galloway, T. S. and Thompson, R. C. (2010). Spatial patterns of plastic debris along estuarine shorelines. Environmental Science Technology, 44(9), 34043409. https://doi.org/10.1021/es903784e

Chen, M.-C. and Chen, T.-H. (2020). Spatial and seasonal distribution of microplastics on sandy beaches along the coast of the Hengchun Peninsula, Taiwan. Marine Pollution Bulletin, 151, 110861. https://doi.org/10.1016/j.marpolbul. 2019.110861

Chu, J., Liu, H. and Salvo, A. (2020). Air pollution as a determinant of food delivery and related plastic waste. Nature Human Behaviour, 5, 212-220. https://doi.org/10.1038/s41562-020-00961-1

Claessens, M., De Meester, S., Van Landuyt, L., De Clerck, K. and Janssen, C. R. (2011). Occurrence and distribution of microplastics in marine sediments along the Belgian coast. Marine Pollution Bulletin, 62, 2199-2204. https://doi.org/10.1016/j.marpolbul.2011.06.030

Clark, A. J., Ross, A. H. and Bon, S. A. F. (2017). Synthesis and properties of polyesters from waste grapeseed oil: Comparison with soybean and rapeseed oils. Polymers and the Environment, 25, 1-10. https://doi.org/10.1007/s10924016-0883-3

Cole, M., Lindeque, P., Halsband, C. and Galloway, T. S. (2011). Microplastics as Contaminants in the marine environment: A review. Marine Pollution Bulletin, 62(12), 2588-2597. https://doi.org/10.1016/j.marpolbul.2011.09.025
Cole, M., Webb, H., Lindeque, P. K., Fileman, E. S., Halsband, C. and Galloway, T. S. (2014). Isolation of microplastics in biota-rich seawater samples and marine organisms. Science Reports, 4(1), 1-8. https://doi.org/10.1038/srep04528

Coppock, R. L., Cole, M., Lindeque, P. K., Queirós, A. M. and Galloway, T. S. (2017). A small-scale portable method for extracting microplastics from marine sediments. Environmental Pollution, 230, 829-837. https://doi.org/10.1016/j.envpol.2017.07.017

Courtene-Jones, W., Quinn, B., Gary, S. F., Moggy, A. O. M. and Noveyanaswamy, B. (2017). Microplastic pollution identified in deep-sea water and ingested by benthic invertebrates in the Rockall Trough, North Atlantic Ocean. Environmental Pollution, 231, 271-280. http://doi.org/10.1016/j.envpol.2017.08.026

Cox, K. D., Covernton, G. A., Davies, H. L., Dower, J. F., Juanes, F. and Dudas, S. E. (2019). Human consumption of microplastics. Environmental Science Technology, 53, 70687074. https://doi.org/10.1021/acs.est.9b01517

De Lucia, G. A., Caliani, I., Marra, S., Camedda, A., Coppa, S., Alcaro, L. and Matiddi, M. (2014). Amount and distribution of neustonic micro-plastic off the western Sardinian coast (Central-Western Mediterranean Sea). Marine Environmental Research, 100, 10-16. https://doi.org/10.1016/j.marenvres.2014.03.017

De Lucia, G. A., Vianello, A., Camedda, A., Vani, D., Tomassetti, P., Coppa, S. and Cicero, A. M. (2018). Seawater contamination in the vicinity of the minor Italian islands caused by microplastic pollution. Water, 10(8), 1108. https://doi.org/10.3390/w10081108

De Witte, B., Devriese, L. and Bekaert, K. (2014). Quality assessment of the blue mussel (Mytilus edulis): Comparison between commercial and wild types. Marine Pollution Bulletin, 85(1), 146-155. https://doi.org/10.1016/ j.marpolbul.2014.06.006

Duchowny, A. and Adams, A. (2021). Compact NMR spectroscopy for low-cost identification and quantification of PVC plasticizers. Molecules, 26(5), 1221. https://doi.org/10.3390/molecules26051221

Elliott, T., Ettlinger, S., Blacklaws, K., Kibara, S., Ndirangu, E., \& Chege, W. (2018). Plastic packaging waste flows in Kenya. Eunomia Research and Consulting Ltd.

Fan, W., Jensen, L. R., Ceccato, M., Quaade, T. S., Gurevich, L., $\mathrm{Yu}$, D. and Smedskjaer, M. M. (2021). Flexible inorganicorganic hybrids with dual inorganic components. Materials Today Chemistry, 22, 100584.

Gang, P. O. and Agatsiva, J. L. (1992). The status of mangroves along the Kenyan coast: A case study of Mida Creek mangroves based on remote sensing. Hydrobiologia, 247(1), 29-36. https://doi.org/10.1007/BF00008202

Geyer, R., Jambeck, J. R. and Law, K. L. (2017). Production, use, and the fate of all plastics ever made. Science advanced, 3(7), e1700872. https://doi.org/10.1126/sciadv.1700782

GOK: Ministry of Environment and Forestry. (2020). Implementation plan for the ban of single use plastics in Kenya. Available at: http://www.environment.go.ke/wpcontent/uploads/2020/03/action-plan.pdf 
G.O.K. (1989). Kilifi District Development Plan 1989-1999. Ministry of Planning and National Development, Nairobi Kenya, pp 224.

Gulmine, J. V., Janissek, P. R., Heise, H. M. and Akcelrud, L. (2002). Polyethene characterisation by FTIR. Polymer Testing, 21(5), 557-563. https://doi.org/10.1016/S01429418(01)00124-6

Guo, X. and Wang, J. (2021). Projecting the sorption capacity of heavy metal ions onto microplastics inglobal aquatic environments using artificial neural networks. Hazardous Materials, 402, 123709. https://doi.org/10.1016/ j.jhazmat.2020.123709

Hidalgo-Ruz, V., Gutw, L., Thomson, R. C. and Thiel, M. (2012). Microplastics in the marine Environment: A review of the methods used for identification and quantification. Environmental Science Technology, 46, 3060-3075. https://doi.org/10.1021/es2031505

Hong, S. H., Shim, W. J. and Jang, M. (2018). Chapter 9 Chemicals associated with marine plastic debris and microplastics: Analyses and contaminant levels. Microplastic Contamination in Aquatic Environments (pp. 271-315). Elsevier. https://doi.org/10.1016/B978-0-12813747-5.00009-6

Jahan, S., Strezov, V., Weldekidan, H., Kumar, R., Kan, T., Sarkodie, S. A., He, J., Dastjerdi, B. and Wilson, S. P. (2019). Interrelationship of microplastic pollution in sediments and oysters in a seaport environment of the eastern coast of Australia. Science of the Total Environment, 695, 133924. https://doi.org/10.1016/j.scitotenv.2019.133924

Jambeck, J. R., Geyer, R., Wilcox, C., Siegler, T. R., Perryman, M., Andrady, A. and Law, K. L. (2015). Plastic waste inputs from land into the ocean. Science, 347(6223), 768-771. https://doi.org/10.1126/science.1260352

Jung, M. R., Horgen, F. D., Orski, S. V., Rodriguez, V., Beers, K. L., Balazs, G. H. and Hyrenbach, K. D. (2018). Validation of ATR FT-IR to identify polymers of plastic marine debris, including those ingested by marine organisms. Marine Pollution Buletin, 127, 704-716. https://doi.org/10.1016/j.marpolbul.2017.12.061

Kairo, J. G., Dahdouh-Guebas, F., Gwada, P. O., Ochieng, C. and Koedam, N. (2002). Regeneration status of Mangrove Forests in Mida Creek, Kenya: A compromised or secured future? AMBIO: A Journal of the Human Environment, 31, 562-568. https://doi.org/10.1579/0044-7447-31.7.562

Kamau, J. N. (2002). Heavy metal distribution and enrichment at Port-Reitz Creek, Mombasa. Western Indian Ocean Journal of Marine Science, 1(1), 65-70.

Kanhai, L. D. K., Officer, R. Lyashevska, O., Thompson, R. C. and O'Connor, I. (2017). Microplastic abundance, distribution, and composition along a latitudinal gradient in the Atlantic Ocean. Marine Pollution Bulletin, 115, 307314. https://doi.org/10.1016/j.marpolbul.2016.12.025

Käppler, A., Fischer, D., Oberbeckmann, S., Schernewski, G., Labrenz, M., Eichhorn, K. J. and Voit, B. (2016). Analysis of environmental microplastics by vibrational microspectroscopy: FTIR, Raman or both? Analytical and Bioanalytical Chemistry, 408(29), 8377-8391. https://doi.org/10.1007/s00216-016-9956-3
Kenya National Bureau of Statistics (KNBS) 2018 population and housing census, volume 1: Population by county and subcounty (2019). www.knbs.or.ke Kenya National Bureau of Statistics.

Kenya Wildlife Services (KWS). (1997). Www.kws.go.ke/ content/watamu-marine-national-park-reserve

Kerubo, J. O., Muthumbi, A. W. N., Onyari, J. M., RobertsonAndersson, D. and Kimani, E. (2021). Microplastics pollution in the sediments of creeks and estuaries of Kenya, western Indian Ocean. African Journal of Marine Science, 43(3), 337-352. https://doi.org/10.2989/1814232X.2021. 1966505

Kerubo, J. O., Muthumbi, A. W., Onyari, J. M., Kimani, E. N. and Robertson-Andersson, D. (2020). Microplastic pollution in the surface waters of creeks along the Kenyan coast, Western Indian Ocean (WIO). Western Indian Ocean Journal of Marine $\quad$ Science, 19(2), 75-88. https://doi.org/10.4314/wiojms.v19i2.6

Khoo, K. S., Ho, L. Y., Lim, H. R., Leong, H. Y. and Chew, K. W. (2021). Plastic waste associated with the COVID-19 pandemic: Crisis or opportunity? Journal of Hazardous Materials, 417, 126108. https://doi.org/10.1016/ j.jhazmat.2021.126108

Kitheka, J. (1998). Groundwater outflow and its linkage to coastal circulation in a mangrove-fringed creek in Kenya. Estuarine, Coastal and Shelf Science, 47(1), 63-75.

Kitheka, J. U., Okemwa, E. N. and Kazungu, J. M. (1999). Monitoring of nutrient levels, turbidity, and sediment transport at Port-Reitz Creek in Kenya. IOC-SIDA. https://doi.org/10.1006/ecss.1998.0325

Kosore, C., Ojwang, L., Maghanga, J., Kamau, J., Kimeli, A., Omukoto, J. and Ndirui, E. (2018). Occurrence and ingestion of microplastics by zooplankton in Kenya's marine environment: First documented evidence. African Journal of Marine Science, 40(3), 225-234. https://doi.org/10.2989/1814232X.2018.1492969

Kukulka, T., Proskurowski, G., Morét-Ferguson, S., Meyer, D. W. and Law, K. L. (2012). The effect of wind mixing on the vertical distribution of buoyant plastic debris. Geophysical Research Letters, 39(7), L07601. https://doi.org/10.1029/ 2012GL051116

Lebreton, L. and Andrady, A. (2019). Futures scenarios of global plastic waste generation and disposal. Palgrave Communications, 5(1), 1-11. https://doi.org/10.1057/ s41599-018-0212-7

Lee, K., Shim, W., Kwon, O., and Kang, J. (2013). Sizedependent effects of micro polystyrene particles in the Marine Copepod Tigriopus japonicus. Environmental Science Technology, 47(19), 11278-11283. https://doi.org/10.1021/ es401932b

Li, P., Wang, X., Su, M., Zou, X., Duan, L. and Zhang, H. (2020). Characteristics of plastic pollution in the environment: A review. Bulletin of Environmental Contamination and Toxicology, 1-8.

Long, Y. Y., Lv, J., Li, B. X. and Liu, Y. G. (2021). Speedy quantitative microstructure determination of Poly (ethylene-co-1-hexene) at triads by $1 \mathrm{H}-13 \mathrm{C}$ twodimensional NMR. Polymer, 229, 123993. 
Ludwig, V., Ludwig, Z. M. D. C., Rodrigues, M. M., Anjos, V., Costa, C. B., das Dores, D. R. S. A. and Soares, F. (2018). Analysis by Raman and infrared spectroscopy combined with theoretical studies on the identification of plasticizer in PVC films. Vibrational Spectroscopy, 98, 134-138. https://doi.org/10.1016/j.vibspec.2018.08.004

Lusher, A. (2015). Microplastics in the marine environment: distribution, interactions and effects. In Marine anthropogenic litter (pp. 245-307). Springer. https://doi.org/10.1007/978-3-319-16510-3_10

Maes, T., Van der Meulen, M. D., Devriese, L. I., Leslie, H. A., Huvet, A., Frère, L., Robbens, J. and Vethaak, A. D. (2017). Microplastics baseline surveys at the water surface and in sediments of the North-East Atlantic. Frontiers Marine Science, 4, 135. https://doi.org/10.3389/fmars. 2017.00135

Mai, L., Bao, L. J., Shi, L., Liu, L. Y. and Zeng, E. Y. (2018). Polycyclic aromatic hydrocarbons affiliated with microplastics in surface waters of Bohai and Huanghai Seas, China. Environmental Pollution, 241, 834-840. https://doi.org/10.1016/j.envpol.2018.06.012

Majewsky, M., Hajo, B., Elisabeth, E. and Harald, H. (2016). Determination of microplastic polyethene (PE) and polypropylene (PP) in environmental samples using thermal analysis (TGA-DSC). Science of the Total Environment, 568, 507-511. https://doi.org/10.1016/ j.scitotenv.2016.06.017

Maritim, P. K., Gachanja, A. N. and Munyao, T. M. (2016). Speciation of Trace Metals $\mathrm{Pb}, \mathrm{Zn}, \mathrm{Cu}$ and $\mathrm{Cd}$ in Surficial Sediment from Makupa Creek Mombasa Coastal Kenya. Open Access Library, 3, e2679. https://doi.org/10.4236/ oalib.1102679

Martinelli, J. C., Phan, S., Luscombe, C. K. and Padilla-Gamino, J. L. (2020). Low incidence of microplastic contaminants in Pacific oysters (Crassostrea gigas Thunberg) from the Salish Sea, USA. Science of the Total Environment, 715, 136826. https://doi.org/10.1016/j.scitotenv.2020.136826

Mathalon, A. and Hill, P. (2014). Microplastic fibres in the intertidal ecosystem surrounding. Halifax Harbor, Nova Scotia. Marine Pollution Bulletin, 81(1), 69-79. https://doi.org/10.1016/j.marpolbul.2014.02.018

Meng, Y., Kelly, F. J. and Wright, S. L. (2020). Advances and challenges of microplastic pollution in freshwater ecosystems: A UK perspective. Environmental Pollution, 256, 113445. https://doi.org/10.1016/j.envpol.2019.113445

Mirriam, W. (2010). Fish Community Structure of a Mangrove Creek, Tudor, Kenya (PhD thesis), Moi University, Kenya.

Mitchell, G., France, F., Nordon, A., Tang, P. L. and Gibson, L. T. (2013). Assessment of historical polymers using attenuated total reflectance-Fourier transform infra-red spectroscopy with principal component analysis. Heritage Science, 1(1), 28. https://doi.org/10.1186/2050-7445-1-28

Moore, C. J. (2008). Synthetic polymers in the marine environment: a rapidly increasing. long-term threat. Environmental Research, 108(2), 131-139. https://doi.org/ 10.1016/j.envres.2008.07.025
Moradi, A., Ramazani, A. and Shahrokhi, M. (2005). Radical chlorination of polyethylene and molecular structure characterization of reaction. Products, Polymer Journal, 37(9), 661-668.

Mwaluma, J., Osore, M., Kamau, J. and Wawiye, P. (2003). Composition, abundance, and seasonality of zooplankton in Mida Creek, Kenya. Western Indian Ocean Journal of Marine Science, 2(2), 147-155. https://doi.org/10.4314/ wiojms.v2i2.28440

Naji, A., Nuri, M. and Vethaak, A. D. (2018). Microplastics contamination in molluscs from the northern part of the Persian Gulf. Environmental Pollution, 235, 113-120. https://doi.org/10.1016/j.envpol.2017.12.046

NEMA, (2017). EMCA (Cap. 387) Nairobi: Republic of Kenya. National Environment Management Authority.

Nguli, M.M. (2006). Water exchange and circulation in selected Kenyan creeks (Ph.D. thesis), University of Dar es Salaam, Tanzania. Available at the Gothernburg University, Department of Earth Science, Section C78.

Nobre, C. R., Santana, M. F. N., Maluf, A., Cortez, F. S. Cesar, A. Pereira, C. D. S. and Turra, A. (2015). Assortment of microplastic toxicity to embryonic development of the sea urchin Lytchinus variegutus (Echinodermata: Echinoidea). Marine Pollution Bulletin, 92, 99-104. https://doi.org/10.1016/j.marpolbul.2014.12.050

Nyamao, W. N. and Ogendi, G. M. (2018). Differential mangroves degradation rates: Case of Tudor and Mwache Creeks, Mombasa, Kenya. International Journal of Environmental Science and Toxicology Research, 6(1), 1-11.

Obiero, J. P. and Onyando, J. O. (2013). Climate. Developments in Earth Surface Processes, 16, 39-50. https://doi.org/10.1016/B978-0-444-59559-1.00005-0

Okuku, E. O., Kiteresi, L. I., Owato, G., Mwalugha, C., Omire, J., Otieno, K. and Mulupi, L. (2020). Marine macro-litter composition and distribution along the Kenyan Coast: The first-ever documented study. Marine Pollution Bulletin, 159, 111497. https://doi.org/10.1016/j.marpolbul.2020.111497

Okuku, E. O., Kiteresi, L., Owato, G., Otieno, K., Omire, J., Kombo, M. M. and Ndwiga, J. (2021). Temporal trends of marine litter in a tropical recreational beach: A case study of Mkomani beach, Kenya. Marine Pollution Bulletin, 167, 112273. https://doi.org/10.1016/j.marpolbul.2021.112273

Okuku, E. O., Ohowa, B., Mwangi, S. N., Munga, D., Kiteresi, L., Wanjeri, V. O., Okumu, S. and Kilonzo, J. (2011). Sewage pollution in the coastal waters of Mombasa City, Kenya: A norm rather than an exception. Environmental Research, 5(4), 865-874.

Okuku, E., Kiteresi, L., Owato, G., Otieno, K., Mwalugha, C., Mbuche, M. and Omire, J. (2021). The impacts of COVID-19 pandemic on marine litter pollution along the Kenyan Coast: a synthesis after 100 days following the first reported case in Kenya. Marine Pollution Bulletin, 162, 111840. https://doi.org/10.1016/j.marpolbul.2020.111840

Onyari, J. M., Mulaa, F., Muia, J. and Shiundu, P. (2008). Biodegradability of poly (lactic acid), preparation, and characterisation of PLA/gum Arabic blends. Polymers and the Environment, 16(3), 205-212. https://doi.org/10.1007/ s10924-008-0096-5 
Osore, M. K. W., Mwaluma, J. M., Fiers, F. and Daro, M. H. (2004). Zooplankton composition and abundance in Mida Creek, Kenya. Zoological Studies, 43, 415-424.

Owuor, M. A., Mulwa, R., Otieno, P., Icely, J. and Newton, A. (2019). Valuing mangrove biodiversity and ecosystem services: A deliberative choice experiment in Mida Creek, Kenya. Ecosystem Services, 40, 101040. https://doi.org/10.1016/j.ecoser.2019.101040

Patel, R. M. (2016). Polyethene. In Multilayer flexible packaging (pp. 17-34). https://doi.org/10.1016/B978-0-323-371001.00002-8

Patterson, J., Jeyasanta, K. I., Sathish, N., Booth, A. M. and Edward, J. P. (2019). Profiling microplastics in the Indian edible oyster, Magallana bilineata collected from the Tuticorin coast, Gulf of Mannar, Southeastern India. Science of the Total Environment, 691, 727-735. https://doi.org/10.1016/j.scitotenv.2019.07.063

Peez, N., Janiska, M. C. and Imhof, W. (2019). The first application of quantitative $1 \mathrm{H}$ NMR spectroscopy as a simple and fast method of identification and quantification of microplastic particles (PE, PET, and PS). Analytical and Bioanalytical Chemistry, 411(4), 823-833. https://doi.org/10.1007/s00216-018-1510-z

Peng, G., Zhu, B., Yang, D., Su, L., Shi, H. and Li, D. (2017). Microplastics in sediments of the Changjiang Estuary, China. Environnemental Pollution, 225, 283-290. https://doi.org/10.1016/j.envpol.2016.12.064

Plastics Europe. (2017). Plastic-The Facts 2017. Brussels: Plastics Europe. Available at: https://www.plastics europe.org/application/files/5715/1717/4180/Plastics the_facts_2017_FINAL_for_website_one_page.pdf

Rahman, M. and Brazel, C. (2004). The plasticizer market.com. An assessment of traditional plasticizers and research trends to meet new challenges. Progress in Polymer Science, 29, 1223-1248.

Researchandmarkets.com. (2021). Plasticizers global market report 2021: COVID-19 impact and recovery to 2030. (Accessed: 28 November 2021).

Rochman, C. (2016). Strategies for reducing ocean plastic debris should be diverse and guided by science. Environmental Research Letters, 11(4), 1748-9336. https://doi.org/10.1088/1748-9326/11/4/041001

Rochman, C., Kross, S. and Armstrong, J. (2015). Scientific evidence supports a ban on microbeads. Environmental Science Technology, 49, 10759-10761. https://doi.org/ 10.1021/acs.est.5b03909

Rodríguez, C., Fossatti, M., Carrizo, D., Sánchez-García, L., de Mello, F. T., Weinstein, F. and Lozoya, J. P. (2020). Mesoplastics and large microplastics along a use gradient on the Uruguay Atlantic coast: Types, sources, fates, and chemical loads. Science of the Total Environment, 721, 137734. https://doi.org/10.1016/j.scitotenv.2020.137734

Ryan, P. G. (2015). A brief history of marine litter research. In M. Bergmann, L. Gutow and M. Klages (Eds.), Marine anthropogenic litter (pp 1-25). Springer. https://doi.org/10.1007/978-3-319-16510-3_1
Sanganyado, E., Bi, R., Teta, C., Buruaem Moreira, L., et al. (2020). Toward an integrated framework for assessing micropollutants in marine mammals: Challenges, progress, and opportunities. Critical Reviews in Environmental Science and Technology, 51(23), 28242871. https://doi.org/10.1016/j.envpol.2013.10.013

Setälä, O., Fleming-Lehtinen, V. and Lehtiniemi, M. (2014). Ingestion and transfer of microplastics in the planktonic food web. Environnemental Pollution, 185, 77-83. https://doi.org/10.1016/j.marpolbul.2016.10.049

Shim, W. J., Hong, S. H., Song, Y. K. and Jang, M. (2016). Identification and quantification of microplastics using Nile Red staining. Marine Pollution Bulletin, 113, 469-776. https://doi.org/10.1016/j.marpolbul.2016.10.049

Silva, A. L. P., Prata, J. C., Walker, T. R., Duarte, A. C., Ouyang, W., Barcelò, D. and Rocha-Santos, T. (2021). Increased plastic pollution due to COVID-19 pandemic: Challenges and recommendations. Chemical Engineering Journal, 405, 126683. https://doi.org/10.1016/j.cej.2020.126683

Smith, P. (2016). Soil carbon sequestration and biochar as negative emission technologies. Global Change Biology, 22(3), 1315-1324. https://doi.org/10.1111/gcb.13178

Thompson, R. C., Olsen, Y., Mitchel, 1. R. P., Davis, A., Rowland, S. J. and John, A. W. (2004). Lost at sea: where is all the plastic? Science, 304, 838. https://doi.org/ 10.1126/science.1094559

UNEP (United Nations Environment Program). (1998). Eastern Africa Atlas of Coastal Resources 1: Kenya. (EAF-14) UNEP. Pp. 119.

Wakwabi, E. O. and Mees, J. (1999). The epibenthos of the backwaters of a tropical mangrove creek (Tudor creek, Mombasa, Kenya). Netherlands Journal of Zoology, 49(3), 189-206.

Wang, T., Li, B., Zou, X., Wang, Y., et al. (2019). Emission of primary microplastics in mainland China: Invisible but not negligible. Water Research, 162, 214-224. https://doi.org/10.1016/j.watres.2019.06.042

Wang, Y., Yuan, Y., Wang, Q., Liu, C., Zhi, Q. and Cao, J. (2020). Changes in air quality related to the control of coronavirus in China: Implications for traffic and industrial emissions. Science of the Total Environment, 731, 139133. https://doi.org/10.1016/j.scitotenv.2020.139133

Wong, J. K. H., Lee, K. K., Tang, K. H. D. and Yap, P. S. (2020). Microplastics in the freshwater and terrestrial environments: Prevalence, fates, impacts and sustainable solutions. Science of the Total Environment, 719, 137512. https://doi.org/10.1016/j.scitotenv.2020.137512

Wright, S. L., Thompson, R. C. and Galloway, T. S. (2013). The physical impacts of microplastics on marine organisms: A review. Environmental pollution, 178, 483-492. https://doi.org/10.1016/j.envpol.2013.02.031

Yap, G. W. and Landoy, R. J. (1986). Development of coastal aquaculture. Report on a survey of the coastal areas of Kenya for shrimp farm development. KEN/80/018. Rome, Italy: FAO. 
Yuan, J., Ma, J., Sun, Y., Zhou, T., Zhao, Y. and Yu, F. (2020). Microbial degradation and other environmental aspects of microplastics/plastics. Science of the Total Environment, 715, 136968. https://doi.org/10.1016/j.scitotenv.2020. 136968
Zhang, Q., Zhao, Y., Du, F., Cai, H., Wang, G. and Shi, H. (2020). Microplastic fallout in different indoor environments. Environmental Science Technology, 54, 6530-6539. https://doi.org/10.1021/acs.est.0c00087

Zhang, Y., Jiao, Y., Li, Z., Tao, Y. and Yang, Y. (2021). Hazards of phthalates (PAEs) exposure: A review of aquatic animal toxicology studies. Science of The Total Environment, 145418. 